\title{
Arbuscular mycorrhizal community structure on co-existing tropical legume trees in French Guiana
}

\author{
Francis Q. Brearley ${ }^{1}$, David R. Elliott ${ }^{1}$, Amaia Iribar $^{2} \&$ Robin Sen ${ }^{1}$ \\ 1) School of Science and the Environment, Manchester Metropolitan University, Chester \\ Street, Manchester, M1 5GD, UK 2) Laboratoire Evolution et Diversité Biologique, UMR \\ 5174 CNRS, University Toulouse III, Toulouse, France
}

\section{f.q.brearley@mmu.ac.uk}

\begin{abstract}
Aims: We aimed at a characterisation of the arbuscular mycorrhizal fungal (AMF) community structure and potential edaphic determinants in the dominating, but poorly described, root-colonizing Paris-type AMF community on co-occurring Amazonian leguminous trees.

Methods: We targeted three highly productive co-occurring leguminous species (Dicorynia guianensis, Eperua falcata and Tachigali melinonii) in species-rich forests on contrasting soil types at the Nouragues Research Station in central French Guiana. Abundant AMF SSU rRNA amplicons (NS31-AM1 \& AML1-AML2 primers) from roots identified via trnL profiling were subjected to denaturing gradient gel electrophoresis (DGGE), clone library sequencing and phylogenetic analysis.

Results: Classical approaches targeting abundant SSU amplicons highlighted a diverse root-colonizing symbiotic AMF community dominated by members of the Glomeraceae. DGGE profiling indicated that, of the edaphic factors investigated, soil nitrogen was most important in influencing the AMF community and this was more important than any host tree species effect.

Conclusions: Dominating Paris-type mycorrhizal leguminous tree species in Amazonian soils host diverse and novel taxa within the Glomeraceae that appear under edaphic selection in the investigated tropical forests. Linking symbiotic diversity of identified AMF taxa to ecological processes is the next challenge ahead.
\end{abstract}

\section{Introduction}

Tropical forests are exceptionally species rich, holding over half the world's species (Dirzo \& Raven 2003; Gibson et al. 2011). Most ecological studies in tropical forests have examined above-ground communities (Ghazoul \& Sheil 2010) whilst microscopic taxa found below-ground such as fungi and bacteria have received considerably less attention, at least partly due to their cryptic nature (Aime \& Brearley 2011). Compared to other microscopic taxa, arbuscular mycorrhizal fungi (AMF; phylum Glomeromycota) have been relatively well studied. These fungi form beneficial root symbiotic 
44 associations, defined by fungal arbuscular structures formed within

45 host cortical cells, in a large proportion of the world's terrestrial flora 46 (Smith \& Read 2008) including many of the more than 20,000 tree 47 species estimated from Neotropical forests (Slik et al. 2015). 48 However, classical morphological descriptions by Gallaud (1904) and 49 numerous subsequent studies, reviewed by Smith and Smith (1997), 50 confirmed that AMF fungi form both Arum- and Paris-type 51 colonization structures in compatible mycorrhizal plant hosts. The 52 former type are characterised as typical AMF but, in the latter, root 53 cortical cells do not host arbuscules but are heavily colonized by 54 intracellular hyphal coils. Tropical forest trees and forest herbs 55 appear to host a predominance of Paris-type mycorrhizas (Alexander 56 1989) including the target leguminous trees at our Amazonian study 57 site in French Guiana (Béreau \& Garbaye 1994; Béreau et al. 2004; 58 de Grandcourt et al. 2004). Whilst it appears that AMF alpha59 diversity can be higher in tropical than temperate ecosystems 60 (Husband et al. 2002; Haug et al. 2010, 2013; Camenzind et al. 61 2014), this is not always the case with overlap shown in the number 62 of AMF taxa recorded from these divergent ecosystems. It is, 63 however, difficult to make robust comparisons due to the paucity of 64 tropical studies coupled with inconsistent methodologies, 65 particularly as the field of molecular ecology advances (e.g. next 66 generation sequencing; Shendure \& Ji 2008).

68 Because mycorrhizal fungi form a key functional interface between 69 plant roots and soil, they play a major role in plant nutrition (Smith \& 70 Read 2008). Leguminous plants and trees also host symbiotic 71 nitrogen-fixing bacteria that require large amounts of phosphorus $(P)$ 72 for nodule development and nitrogenase functioning (e.g. Mortimer 73 et al. 2008 and references therein). Nitrogen (N) fixation in 74 leguminous plants in general and tropical trees in particular is 
75 therefore highly dependent upon efficient P uptake, especially in P76 deficient tropical soils, which is mediated by the AMF symbiosis 77 (Plassard \& Dell 2010). In addition, AMF are known to be important 78 in structuring plant communities with different taxa or associations 79 of taxa having differential effects on plant growth (van der Heijden 80 et al. 1998; Munkvold et al. 2004; Koch et al. 2006; Roger et al. 81 2013). For example, Kiers et al (2000) demonstrated differential 82 responses to AMF inoculum from conspecific or heterospecific 83 tropical tree seedlings and Pizano et al. (2011) found that AMF from 84 tropical landslide sites had differing effects on plant growth 85 compared to those from light-gap sites, both studies indicating the 86 potential role of AMF in influencing plant communities.

87 Understanding the determinants of species distributions, through 88 studying their niche requirements, and elucidating ecological

104 In this study, we examined the root associated AMF fungal 105 community on three co-occurring leguminous tree species of French 
106 Guiana where legumes form many of the commonest tree species,

107 making a significant contribution to stand basal area (ter Steege et

108 al. 2006). We hypothesised that: i) the Paris-mycorrhizal status of 109 the target legume tree species could result from colonization by 110 novel AMF taxa, ii) host tree and soil edaphic specific responses 111 would be detectible in root colonizing fungal communities but iii) the 112 co-ocurring trees would form a core AMF community with the 113 potential to form common mycelial networks.

\section{Methods}

\section{Study site}

117 The study was conducted at the Nouragues Research Station (within 118 a National Nature Reserve) in central French Guiana (Bongers et al. 119 2001; http://www.nouragues.cnrs.fr) with a diverse tree flora typical 120 of much of the Guiana Shield (ter Steege et al. 2006; Gonzalez et al. 121 2009). The sampling was restricted to the Inselberg camp area $122\left(4^{\circ} 05^{\prime} \mathrm{N} ; 52^{\circ} 41^{\prime} \mathrm{W}\right)$ in minimally disturbed tropical forest where two 123 large sampling plots ('Grand Plateau' and 'Petit Plateau') have been 124 delimited. These two plots have differing edaphic conditions: the 125 Grand Plateau is based on a metamorphic geology with more fertile 126 clay-rich soils and the Petit Plateau is based on a granitic geology 127 with more sandy soils that are less fertile, although both are Ultisols 128 (Poszwa et al. 2009). The annual rainfall is around $2900 \mathrm{~mm}$ with a 129 drier season from late August to early November.

\section{Study species}

132 We investigated three legume species in different tribes of the 133 Caesalpinioideae: Dicorynia guianensis Amshoff (tribe Cassieae), 134 Tachigali melinonii (Harms) Zarucchi \& Herend. (syn. Sclerolobium 135 melinonii Harms; tribe Caesalpinieae) and Eperua falcata Aublet 
136 (tribe Detarieae). The former two species are among the most 137 important trees, in terms of carbon cycling, in the Amazon basin 138 (Fauset et al. 2015). The three species have contrasting root 139 morphologies with Dicorynia guianensis and Tachigali melinonii 140 being similar to one another with thin, highly branched roots in 141 contrast to Eperua falcata that had thicker, poorly branching root 142 systems with short roots on long axes (Béreau \& Garbaye 1994; 143 Supplementary Figure 1). All three species form Paris-type 144 mycorrhizal associations (Béreau \& Garbaye 1994; Béreau et al. 145 2004; de Grandcourt et al. 2004). Many Caesalp legumes possess 146 ectomycorrhizal (ECM) associations (Smith \& Read 2008) but 147 following a careful visual assessment of sampled roots, no obvious 148 EcM development was observed. Dicorynia guianensis and Tachigali 149 melinonii form prominent nodules and Eperua falcata has nodule-like 150 structures on the roots whose function is not entirely clear (Sprent 151 2001).

\section{Field sampling}

154 Root samples were obtained from 12-16 randomly selected trees 155 each of the three target species in August and September 2009 156 (trees were up to $1 \mathrm{~m}$ diameter; mean $=50.3 \pm S D 20.3 \mathrm{~cm}$ ). At 157 each tree, roots were exposed by careful excavation enabling them 158 to be traced to a distance of about 1.0 to $1.5 \mathrm{~m}$ from the trunk 159 (Supplementary Figure 1a). Four samples of fine root material were 160 cut away from the surrounding friable organic soil with any soil 161 adhering to the roots brushed off. Root samples from each tree were 162 combined together into a single plastic vial filled with silica gel for 163 rapid drying. Soil samples were taken from the areas immediately 164 adjacent to root collection and combined into a single sample. They 165 were subsequently air-dried in the field and returned to the UK for 166 analysis. 


\section{DNA extraction}

169 In the laboratory, dried root material was finely chopped and 170 homogenised aseptically using a sterile scalpel and larger diameter

171 sections were removed until all fragments were less than $2 \mathrm{~mm}$ in 172 length. No obvious spore contamination in the rhizoplane was 173 detected in these root fragments. DNA extraction was performed on 174 the homogenised roots using a modification of the method of 175 Heinonsalo et al. (2001) developed for highly pigmented Scots pine 176 roots/mycorrhizas. Briefly, two extractions were made from each 177 root sample starting with $5 \mathrm{mg}$ material each. The roots were 178 further ground using a micro-pestle and fine quartz sand, then $1 \mathrm{ml}$ 179 CTAB buffer with $1 \%$ PVP was added and the sample was 180 periodically ground during an incubation at $65{ }^{\circ} \mathrm{C}$ for 1 hour. The 181 two extractions were then centrifuged at 16,000 RCF for 5 minutes 182 and the supernatants were separately extracted twice with equal 183 volumes of chloroform. After extraction, the two aqueous layers 184 were combined and precipitated together with an equal volume of 185 chilled isopropanol. The DNA was collected by centrifuging at $18616,000 \mathrm{RCF}$ for 30 minutes then removing the supernatant, then the 187 pellet was washed twice by applying $200 \mu$ chilled $70 \%$ ethanol and 188 centrifuging for 5 minutes at 7,000 RCF. The dried pellets were 189 rehydrated in $25 \mu \mathrm{l} \mathrm{TE}$ buffer and stored at $-20^{\circ} \mathrm{C}$ until use.

191 Host plant species validation by trnL amplicon fragment 192 length analysis

193 Although all the root samples were visually traced during sampling, 194 we considered it prudent to verify the identity and purity of root 195 samples. We used a length heterogeneity PCR approach, based 196 upon the work of Ridgway et al. (2003), to achieve this. The 197 Genbank database was used to predict amplicon sizes for a PCR of 
198 the plastid trnL intron using primers $\mathrm{c}$ and $\mathrm{d}$ from Taberlet et al. 199 (1991). PCRs were performed using the conditions described by 200 Gonzalez et al. (2009), but the c primer was modified with CY5 on 201 the 5 ' end to enable compatibility with the Beckman fragment 202 analysis system. Amplicon lengths were measured and quantified 203 using a Beckman CEQ 8000 automated sequencer in fragment 204 analysis mode. Direct sequencing of some of the amplicons was 205 performed to check the specificity of the PCR and confirm tree 206 identities. The $c$ and d primers Taberlet et al. (1991) were used to 207 obtain sequence reads using an Applied Biosystems 3730xl 208 sequencer.

\section{Mycorrhizal community profiling}

211 The AMF community associated with each tree was compared using 212 denaturing gradient gel electrophoresis (DGGE) to generate a 213 community fingerprint from an amplified fragment of the fungal 214 small sub-unit rRNA gene. PCR and DGGE were performed according 215 to the method of Öpik et al. (2003), using primers AM1 (Helgason et 216 al. 1998) and NS31 (Simon et al. 1992). A GC clamp was added to 217 the 5' end of NS31 primer to stabilize the melting behaviour of the 218 DNA fragments. PCRs contained $2.5 \mathrm{U}$ Taq (Bioline), $5 \mu \mathrm{l} 10 \times \mathrm{NH}_{4}$ 219 reaction buffer, $1.5 \mathrm{mM} \mathrm{MgCl} 2,200 \mu \mathrm{M}$ of each dNTP, $0.2 \mu \mathrm{M}$ of each 220 primer, and were made up to $50 \mu \mathrm{l}$ volume with water and DNA 221 template; they were performed in an MJ Research PTC-200 thermal 222 cycler following cycling parameters in Öpik et al. (2003). DGGE was 223 carried out on the Bio-Rad DCode universal mutation detection 224 system, using $6 \%$ polyacrilamide gels, with urea-formamide 225 denaturant gradients of 22 to $35 \%$. Electrophoresis was run at 60 $226 \stackrel{\circ}{ } \mathrm{C}$ and $75 \mathrm{~V}$ for 8 hours, with $32 \mathrm{ng}$ DNA loaded into each well. Gels 227 were stained with SYBR Gold (Molecular Probes, Leiden, The 228 Netherlands) and digitized using GeneGenius Imaging System from 
229 Syngene. We ran two DGGE gels: the first had sixteen trees of 230 Tachigali melinonii ("Tachigali gel") and the second had a subset of 231 nine of those sixteen trees plus nine Dicorynia guianensis and four 232 Eperua falcata ("Mixed gel"). Gel images were converted to a 233 presence/absence matrix for each band position based on a 234 systematic procedure using the plot RGB profile function of ImageJ 235 (Schneider et al. 2012) to extract pixel values for each lane, followed 236 by peak detection using LabPlot (http://labplot.sourceforge.net). To 237 correct for slight skew in the gels, coloured reference lines were 238 added across the gel images linking lane markers and prominent 239 reference bands before peak detection. The signatures of these 240 lines in the RGB pixel profiles from ImageJ were used to ensure 241 accurate alignment of lane profiles before peak detection.

\section{Determination of mycorrhizal taxa}

244 Whilst DGGE requires relatively short, variable PCR products to 245 achieve good separation of bands on the gel, for accurate 246 phylogenetic classification a longer sequence is preferable. For this 247 part of the study, we therefore used primers AML1 and AML2 that 248 are reported to have better specificity and coverage of known AMF 249 taxa compared to the AM1 and NS31 primers used for DGGE (Lee et 250 al. 2008). We chose six samples: three geographically close $(<300$ $251 \mathrm{~m}$ ) trees of each species from each of the Grand and Petit Plateaus. 252 PCR products were produced using the protocol described by Lee et 253 al. (2008), then cloned into E. coli using an Invitrogen Topo TA 254 cloning kit. Ten positive transformants from each tree were used 255 directly in a colony PCR (Elliott et al. 2005) using vector primers 256 M13F and M13R to check the insert size (approximately 800 base 257 pairs). Forty-eight successful inserts were sequenced from the T3 258 priming site using an Applied Biosystems 3730xl sequencer. 
260 Sequences from forward and reverse primers were assembled using 261 contig assembly program (Huang 1992) and single coverage regions 262 were discarded. A total of 23 double coverage sequences were 263 obtained and these were clustered at $99 \%$ similarity cutoff using cd264 hit-est (Huang et al. 2010) to identify unique sequences. 265 Approximate species-level OTUs were identified using UCLUST 266 (Edgar 2010) with a $97 \%$ similarity threshold. A neighbour-joining 267 phylogenetic tree was constructed from the unique sequences that 268 exceeded 450 base pairs in length. We included the top match from 269 MaarjAM (Öpik et al. 2010) for each of our sequences plus all 270 sequences associated with two of our host plants (presented in Öpik 271 et al. 2013) in addition to several globally distributed taxa to provide 272 a wider context. We also included the three top matching 273 sequences from a BLAST search on Genbank and any closely 274 matching named taxa. In some cases, relevant sequences were 275 excluded because the sequence regions did not overlap sufficiently 276 with those reported in this study. ClustalW (Thompson et al. 1994) 277 was used to align the sequences and all gaps were removed before 278 generation of the distance matrix (Kimura 1980) and neighbour279 joining phylogenetic tree (Saitou \& Nei 1987), using the APE 280 package (Paradis et al. 2004) for R (R Core Team 2015).

\section{Soil analyses}

283 All analyses were conducted in duplicate on soils that had been 284 ground to pass a $1 \mathrm{~mm}$ sieve. The moisture content of the air-dried 285 soil was determined by heating $5 \mathrm{~g}$ sub-samples to $105^{\circ} \mathrm{C}$ for $24 \mathrm{~h}$. 286 Soil $\mathrm{pH}$ was measured by adding $5 \mathrm{~g}$ of soil to $12.5 \mathrm{ml}$ of deionised 287 water; it was stirred and left to equilibrate for $1 \mathrm{~h}$ before the $\mathrm{pH}$ was 288 measured with a Sartorius PB-11 pH meter. Carbon and $\mathrm{N}$ were 289 determined on a LECO TruSpec elemental analyser. Total P was 290 determined by digesting $0.25 \mathrm{~g}$ samples in $5 \mathrm{ml}$ of concentrated 
291 sulphuric acid (with a lithium sulphate/selenium (100:1) catalyst) for 2928 hours at $375{ }^{\circ} \mathrm{C}$. Samples were then made up to $50 \mathrm{ml}$ in 293 deionised water and analysed on a Varian Vista AX Inductively 294 Coupled Plasma Optical Emission Spectrometer (ICP-OES). Cations 295 ( $\mathrm{P}, \mathrm{K}, \mathrm{Ca} \& \mathrm{Mg}$ ) were extracted from $2.5 \mathrm{~g}$ samples that were shaken 296 with $25 \mathrm{ml}$ of Mehlich 1 solution for ten minutes before being filtered 297 and analysed on a Thermo iCAP 6300 Duo ICP-OES.

\section{Statistics}

300 Rarefaction curves were calculated in Estimates (100 301 randomisations). Redundancy analysis was performed using the 302 Vegan package (Oksanen et al. 2015) for R (R Core Team 2015) with 303 a backwards-stepwise approach to select constraining variables. We 304 tested whether the AMF community differed in relation to soil 305 properties or host tree species using a PerMANOVA (Jaccard index, 306999 permutations), also in the Vegan package.

\section{Results}

\section{Arbuscular mycorrhizal SSU amplification}

310 PCR success varied and was limited for more recalcitrant samples of

311 Eperua falcata that had thick and highly pigmented roots (c. $40 \%$ ) 312 when compared with Dicorynia guianensis (c. $75 \%$ ) and Tachigali 313 melinonii (100\%). Difficulties amplifying the host trnL marker 314 mirrored difficulties amplifying the fungal SSU; therefore AMF 315 amplification failure was most likely due to PCR inhibition rather 316 than absence of fungi in the samples.

318 Plant species validation by trnL amplicon sizes

319 Double-coverage $t r n L$ sequences were obtained from Dicorynia 320 guianensis and Eperua falcata (GenBank accessions: PENDING) with 
321 99-100\% identity to publicly available trnL sequences from the 322 target trees; sequencing of amplicons from Tachigali melinonii was 323 unsuccessful. In almost all samples, the dominant trnL fragment 324 sizes were within two base pairs of the predicted length (Table 1). 325 We removed five samples from subsequent analyses; one had a 326 much shorter fragment than expected (indicating that the tree was 327 probably identified incorrectly) and four others had secondary peaks 328 that were $10 \%$ or more of the height of the main peak (indicating 329 probable contamination with roots of other plants).

\section{Mycorrhizal community profiling by DGGE}

332 Rarefaction curves (and comparison with Chaol values) suggest that 333 our sampling was sufficiently extensive to describe the AMF 334 community on Dicorynia guianensis and Tachigali melinonii but not 335 Eperua falcata with around 30 bands found for the former two 336 species and 25 for the latter (Fig. 1a) and a total of 34 bands for the 337 community as a whole (using the Mixed gel). The Chaol estimate 338 for the AMF community as a whole was $34.7 \pm$ SD 1.3 indicating 339 extensive sampling. Within a species, c. 35-55\% of the bands were 340 rare (i.e. restricted to one or two individual trees) with only a small 341 proportion $(<12 \%$ ) found on more than $80 \%$ of the trees within a 342 species (Fig. 1b). Around half of the bands were found on all three 343 tree species with few restricted to a single host - mostly to Dicorynia 344 guianensis (Fig. 2). Of the bands that were shared between species, 345 most were rare with the exception of one band that was found on 346 around $80 \%$ of Dicorynia guianensis trees but no Eperua falcata 347 trees.

349 Root-colonizing mycorrhizal community responses to tree 350 species and soil chemistry 
351 The soils were acidic and low in nutrients but there were significant 352 differences between the Grand and Petit Plateau, with the Petit 353 Plateau soils slightly more acidic and lower in the major plant 354 nutrients (Table 2). Consequently, there were also differences 355 between the tree species in their surrounding edaphic variables 356 (Table 2) as Dicorynia guianensis was more commonly sampled on 357 the Petit Plateau whereas Eperua falcata and Tachigali melinonii 358 were more commonly sampled on the Grand Plateau. In particular, 359 soils surrounding Eperua falcata were highest in $\mathrm{C}, \mathrm{N}$ and 360 extractable $\mathrm{P}$ and cations whereas those surrounding Dicorynia 361 guianensis were lowest in all measured nutrients (Table 2).

The step-wise redundancy analysis model building process selected 364 soil $\mathrm{N}$ as the only constraining variable describing the AMF community structure (Fig. 3); $\mathrm{N}$ also appeared to separate the host 366 trees on axis RDA1. The significance on $\mathrm{N}$ on the AMF community was confirmed by PerMANOVA ( $F=1.93, r^{2}=0.089, p=0.039$ ).

368 However, different host tree species were found on soils of differing 369 N-status (Table 2) and this might have influenced the AMF 370 community through host selection although this was not a significant 371 determinant of at the data resolution available in this study ( $F=$ $\left.3720.91, r^{2}=0.084, p=0.64\right)$.

\section{Phylogeny of mycorrhizal taxa}

375 All of the sequences found on the six trees (Genbank accessions: KR706472-KR706484) were from the family Glomeraceae (within the 377 order Glomerales). They were grouped into eight approximate 378 species-level groups with $>97 \%$ similarity; six of these were 379 singletons found on one tree only. The Chao 1 estimate of the 380 number of phylogroups was 17: this was half that estimated from 381 the DGGE bands although in closer agreement with the number 
382 predicted when rarefied to six samples (24.6 \pm SD 1.7). Our 383 sequences did not match with any named AMF taxa, and, 384 interestingly, did not cluster closely with sequences from two of the 385 same host species in a site in French Guiana about 125 km distant 386 (Öpik et al. 2013) (Fig. 4).

\section{Discussion}

389 There remains a critical gap in the literature relating to tropical 390 mycorrhizal community dynamics that, in boreal and temperate biomes, are known to underpin ecosystem productivity and multifunctionality (Smith and Read, 2008; van der Heijden et al. 2015). Earlier research, that had targeted the same species-rich Amazonian forests in French Guiana, highlighted a predominance of Paris-, as opposed to more commonly studied, Arum-type mycorrhizal colonization of leguminous trees (Béreau \& Garbaye 1994; Béreau et al. 2004; de Grandcourt et al. 2004). We provide here the first report on the diversity and identity of AMF known to form Paris- type mycorrhiza on three co-occurring leguminous trees 401

402 The main aim of our study was not to exhaustively recover AMF 403 diversity, for which we would have used a specific set of primers for 404 each order, but to determine the abundant root-associated taxa in 405 our study system that are likely to be symbiotically active. This 406 approach yielded an estimate of 34 AMF taxa detected in roots on 407 the basis of SSU-DGGE banding that has been shown, via individual 408 band sub-cloning and sequencing, to underestimate AMF root409 colonizing diversity (Öpik et al. 2003), although it assumes we did 410 not have any non-specific amplification from other fungal phyla 411 (Kohout et al. 2014). Our estimate still compares with other tropical 
412 studies employing various classical and next generation sequencing 413 methodologies, for example, Aldrich-Wolfe (2007) found 31 414 phylotypes by T-RFLP in Costa Rica, Husband et al. (2002) found 30 415 taxa using a cloning and Sanger sequencing approach in Panama 416 and Camenzind et al. (2014) found 74 taxa using 454417 pyrosequcncing in Ecuador. However, comparisons are difficult 418 between studies due to differing primers, sequencing platforms and 419 clustering approaches. It appeared that our sampling was saturated 420 with eight to ten samples, sufficient to sample the root-colonizing 421 AMF community fully by DGGE.

423 Members of the Glomeraceae dominated the AMF community with 424 no evidence of the abundant presence of members from other 425 families or orders in the Glomeromycota. This was somewhat 426 surprising given the high abundance of Acualosporaceae in tropical 427 spore-counting studies (e.g. Lovelock et al. 2003; Stürmer \& Siqueira 428 2011; de Oliveira Freitas et al. 2014) including at our study site 429 (Martin et al. 2001; Oehl \& Brearley, unpublished data). It should be 430 stressed that this is not a limitation of the primers developed by Lee 431 et al. (2008) that efficiently amplify across the phylum. At least part 432 of this restricted phylogenetic coverage is likely due to the small 433 number of sequences found so we should be careful not to over434 interpret from this small dataset. However, it raises the interesting 435 possibility that a phylogenetically restricted subset of AMF taxa 436 preferentially form structurally distinct Paris-type mycorrhizal 437 associations. Öpik et al. (2013), employing 454 pyrosequencing at a 438 similar study site in French Guiana, also found a similarly restricted 439 subset of AMF taxa on two of our study species. Paris-type 440 mycorrhizas appear to support extensive intracellular fungal coiling 441 (Smith and Read 2008) that could physically prevent colonization by 442 other AMF taxa thus restricting functional taxa representation due to 
443 priority effects (Hepper et al. 1988; Werner and Kiers, 2015). The 444 restricted taxa detected on our target tree roots could, therefore, 445 represent a natural manifestation of a phenomenon that has, to 446 date, only been described in controlled laboratory experiments with 447 young seedlings. Our findings also support the hypothesis of Kivlin 448 et al. (2011) of phylogenetic clustering within sites; perhaps, in this 449 case, due to all the host trees being within the same family. That 450 the identified taxa found mostly formed highly-supported unique 451 clusters when compared to AMF taxa identified by Öpik et al. (2013) 452 on two of the same host tree species additionally supports the 453 hypothesis of Kivlin et al. (2011) of high beta diversity in AMF. 454 Finally, there is the possibility that these are legume specialist AMF 455 as Sheublin et al. (2004) found clear differences between the AMF 456 communities on legumes and non-legumes in a Dutch grassland.

458 The clearest relationship between soil nutrients and AMF taxa 459 representation was seen for soil N. A related study (Camenzind et 460 al. 2014) in species rich tropical montane forest found reduced AMF 461 species richness in bulked root samples in response to $\mathrm{N}$ and $\mathrm{P}$. 462 Nitrogen input in native forests will be greatly dependent on 463 anthropogenic deposition rates but also associative and symbiotic $\mathrm{N}$ 464 fixation involving legumes. The legume tree species in this study 465 are productive members of the community and will contribute 466 significant organic $N$ to the soil via litter inputs. Spatial variability in $467 \mathrm{~N}$ content was shown in these species-rich forest systems that could 468 select for AMF taxa with enhanced potential organic N-mobilizing 469 activities (Hodge 2014). For example, Martin et al. (2001) showed 470 soils under Eperua falcata to be more enriched in $\mathrm{N}$ than those 471 under Dicorynia guianensis in common with this study. In our study, 472 it appeared that soil $\mathrm{N}$ had a greater effect that host species 473 (although there was non-random association of tree species with 
474 particular edaphic conditions) concurring with other recent studies 475 pointing towards edaphic factors playing a more important role than 476 host species in structuring AMF communities (Fitzsimmons et al. 477 2008; Dumbrell et al. 2010; Ji et al. 2012). With regard to common 478 mycelial networks, our data provided some evidence of potential 479 inter- and intra- host species networking potential. Mechanisms 480 driving restriction to limited common AMF-forming taxa in these 481 productive leguminous hosts may have evolved to ensure 482 networking within $\mathrm{N}$-fixing trees in a highly resource competitive 483 environment.

485 For unequivocal identification of the host species in systems with 486 diverse vegetation, the plastid trnL region offers a robust and rapid 487 marker for confirmation of root sample identity with minor species488 specific trnL length variations likely reflecting intra-specific variation 489 within the study site. Zeng et al. (2015) recently reported 490 successful root identification of 11 tree species in a Chinese 491 subtropical forest via trnL sequencing. Although many studies adopt 492 a root-tracing approach, the important strategy taken here to 493 confirm host species via molecular tools is rarely adopted and we 494 promote this as a straightforward and appropriate method for 495 certainty in mixed species communities where reference material is 496 available. As well as trnL (Dumbrell et al. 2010; Zeng et al. 2015), 497 other suitable gene regions might include trnH-psbA (Jones et al. 498 2011), rbcL or matK (CBOL Plant Working Group 2009).

500 One of the advantages to our 'classical' sequencing approach is that 501 we detected the taxa that are more abundant in the tree roots and, 502 therefore, functionally most important in terms of mutualistic 503 associations; furthermore, it allows us to avoid sampling low-density 504 'contaminant' hyphae in the rhizoplane or spores simply present on 
505 the plant roots that would be picked up by extensive next506 generation sequencing but are not forming functional AMF. If we 507 wished to sample the soil AMF community exhaustively then next508 generation sequencing or DNA metabarcoding would effectively 509 allow this more in-depth examination of the community (e.g. Öpik et 510 al. 2013).

512 What is the functional importance of root symbiotic AMF diversity 513 and what are all these fungi doing in the ecosystem? For example, 514 the mycorrhizal response to AMF inoculation in Eperua falcata is less 515 than Dicorynia guianensis (de Grandcourt et al. 2004) and this may 516 be influenced by this species' preference for nitrate (Schimann et al. 517 2012) mediated by root exudate influence on the rhizosphere 518 microbial community (Michalet et al. 2013). If AMF communities 519 that have different functions (such as P-mining ability) are spatially 520 separated then they have the potential to influence seedling 521 diversity in tropical forests and hence contribute to the high 522 diversity of these ecosystems.

\section{Acknowledgements}

525 We thank Centre National de la Recherche Scientifique for managing 526 the Nouragues Research Station and funding this study through

527 Project Amazonie and Manchester Metropolitan University for 528 providing a research assistantship to DRE. We are very grateful to 529 Jérôme Chave for his support of this project and Philippe Gaucher 530 and Patrick Châtelet who were of great help during fieldtrip 531 preparation and sampling. Stavros Veresoglou, John Davison and 532 anonymous reviewers are thanked for their comments on the 533 manuscript. This project was also partly funded from 534 "Investissement d'Avenir" grants managed by Agence Nationale de 
Author contributions Designed the study and obtained funding: $\mathrm{FQB} \&$ \&S; performed the study: FQB, DRE \& Al; analysed the data:

\section{References}

543

544

545 DRE \& FQB; wrote the manuscript: FQB, RS \& DRE.

Aime MC, Brearley FQ (2012) Tropical fungal diversity: closing the gap between species estimates and species discovery. Biodivers Conserv 21:2177-2180. doi:10.1007/s10531-012-0338-7.

Aldrich-Wolfe L (2007) Distinct mycorrhizal communities on new and established hosts in a transitional tropical plant community. Ecology 88:559-566. doi:10.1890/05-1177.

Alexander IJ (1989) Mycorrhizas in tropical forests. In: Mineral Nutrients in Tropical Forest and Savanna Ecosystems. Ed. J Proctor. pp. 169-188. Blackwell Scientific Publications, Oxford, UK.

Béreau M, Garbaye J (1994) First observations on the root morphology and symbioses of 21 major tree species in the primary tropical rain forest of French Guyana. Ann Sci For 51:407-416. doi: 10.1051/forest:19940406.

Béreau M, Louisanna E, Garbaye J (2004) Mycorrhizal symbiosis in the tropical rainforest of French Guiana and its potential contribution to tree regeneration and growth. In: Ecology and Management of a Neotropical Rainforest (eds S Gourlet-Fleury, J-M Guehl, O Laroussinie), pp. 114-119. Elsevier, Paris, France.

Bongers F, Charles-Dominique P, Forget PM, Théry M (2001) Nouragues: Dynamics and Plant-Animal Interactions in a Neotropical Rainforest. Kluwer Academic Publishers, Dordrect, The Netherlands.

Camenzind T, Hempel S, Homeier J, Horn S, Velescu A, Wilcke W, Rillig MC (2014) Nitrogen and phosphorus additions impact arbuscular mycorrhizal abundance and molecular diversity in a tropical montane forest. Glob Chang Biol 20:3646-3659. doi:: 10.1111/gcb.12618.

CBOL Plant Working Group (2009) A DNA barcode for land plants. Proc Natl Acad Sci USA 106:12794-12797. doi:10.1073/pnas.0905845106.

de Grandcourt A, Epron D, Montpied P, Louisanna E, Béreau M, Garbaye J, Guehl J-M (2004) Contrasting responses to mycorrhizal inoculation and phosphorus availability in seedlings of two tropical rainforest tree species. New Phytol 161:865-875. doi:10.1046/j.1469-8137.2004.00978.x.

de Oliveira Freitas R, Buscardo E, Nagy L, dos Santos Maciel AB, Carrenho R, Luizão RCC (2014) Arbuscular mycorrhizal fungal communities along a pedo-hydrological gradient in a Central Amazonian terra firme forest. Mycorrhiza 24:21-32. doi: 10.1007/s00572-013-0507-x.

Dirzo R, Raven PH (2003) Global state of biodiversity and loss Annu Rev Environ Resour 28:137-167. doi:10.1146/annurev.energy.28.050302.105532.

Dumbrell AJ, Nelson M, Dytham C, Helgason T, Fitter AH (2010) Relative roles of niche and neutral processes in structuring a soil microbial community. ISME J 4:337-345. doi:10.1038/ismej.2009.122.

Edgar RC (2010) Search and clustering orders of magnitude faster than BLAST. Bioinformatics 26:2460-2461. doi: 10.1093/bioinformatics/btq461. 
Elliott DR, Wilson M, Buckley CMF, Spratt DA (2005) Cultivable oral microbiota of domestic dogs. J Clin Microbiol 43:5470-5476. doi:10.1128/JCM.43.11.54705476.2005.

Fauset $S$ et al. (2015) Hyperdominance in Amazonian forest carbon cycling. Nat Commun 6:6857. doi: 10.1038/ncomms7857.

Fitzsimons MS, Miller RM, Jastrow JD (2008) Scale-dependent niche axes of arbuscular mycorrhizal fungi. Oecologia 158:117-127. doi: 10.1007/s00442008-1117-8.

Gallaud I. (1904). Études sur les Mycorrhizes Endotrophes. Le Bigot Frères, Lille, France.

Ghazoul J, Sheil D (2010) Tropical Rain Forest Ecology, Diversity, and Conservation. Oxford University Press, UK.

Gibson L, Lee TM, Koh LP, Brook BW, Gardner TA, Barlow J, Peres CA, Bradshaw CJA, Laurance WF, Lovejoy TE, Sodhi NS (2011) Primary forests are irreplaceable for sustaining tropical biodiversity. Nature 478 : 378-381. doi:10.1038/nature10425.

Gonzalez MA, Baraloto C, Engel J, Mori SA, Pétronelli P, Riéra B, Roger A, Thébaud C, Chave J (2009) Identification of Amazonian trees with DNA barcodes. PLoS ONE 4:e7483. doi:10.1371/journal.pone.0007483.

Haug I, Wubet T, Weiß M, Aguirre N, Weber M, Günter S, Kottke I (2010) Speciesrich but distinct arbuscular mycorrhizal communities in reforestation plots on degraded pastures and in neighboring pristine tropical mountain rain forest. Trop Ecol 51:125-148. DOI

Haug I, Setaro S, Suárez JP (2013) Reforestation sites show similar and nested AMF communities to an adjacent pristine forest in a tropical mountain area of South Ecuador. PLOS ONE 8:e63524. doi:10.1371/journal.pone.0063524.

Hazard C, Gosling P, van der Gast CJ, Mitchell DT, Doohan FM, Bending GD (2013) The role of local environment and geographical distance in determining community composition of arbuscular mycorrhizal fungi at the landscape scale. ISME J 7:498-508. doi:10.1038/ismej.2012.127.

Heinonsalo J, Jørgensen KS, Sen R (2001) Microcosm-based analyses of Scots pine seedling growth, ectomycorrhizal fungal community structure and bacterial carbon utilization profiles in boreal forest humus and underlying illuvial mineral horizons. FEMS Microbiol Ecol 36:73-84. doi:10.1111/j.15746941.2001.tb00827.x.

Helgason T, Daniell TJ, Husband R, Fitter AH, Young JPW (1998) Ploughing up the wood-wide web? Nature 394:431. doi:10.1038/28764.

Helgason T, Merryweather JW, Young JPW, Fitter AH. (2007) Specificity and resilience in the arbuscular mycorrhizal fungi of a natural woodland community. J Ecol 95: 623-630. doi:10.1111/j.1365-2745.2007.01239.x.

Hepper CM, Azcon-Aguilar C, Rosendahl S, Sen R (1988) Competition between three species of Glomus used as spatially separated introduced and indigenous mycorrhizal inocula for leek (Allium porrum L.). New Phytol 110:207-215. doi:10.1111/j.1469-8137.1988.tb00254.x.

Hodge, A. (2014) Interactions between arbuscular mycorrhizal fungi and organic material substrates. Adv Appl Microbiol 89:47-99. doi:10.1016/B978-0-12800259-9.00002-0.

Huang $X$ (1992) A contig assembly program based on sensitive detection of fragment overlaps. Genomics 14:18-25. doi:10.1016/S0888-7543(05)802770 .

Huang Y, Niu B, Gao Y, Fu L, Li W (2010) CD-HIT Suite: a web server for clustering and comparing biological sequences. Bioinformatics 26:680-682. doi:10.1093/bioinformatics/btq003. 
661

662

663

664

665

666

667

668

669

670

671

672

673

674

675

676

677

678

679

680

681

682

683

684

685

686

687

688

689

Husband R, Herre EA, Turner SL, Gallery R, Young JPW (2002) Molecular diversity of arbuscular mycorrhizal fungi and patterns of host association over time and space in a tropical forest. Mol Ecol 11:2669-2678. doi:10.1046/j.1365294X.2002.01647.X.

Jackson CR, Roden EE, Churchill PF (2000) Denaturing gradient gel electrophoresis can fail to separate 16S rDNA fragments with multiple base differences. Mol Biol Today 1:49-51. DOI

Ji B, Bentivenga SP, Caspar BB (2012) Comparisons of AM fungal spore communities with the same hosts but different soil chemistries over local and geographical scales. Oecologia 168:187-197. doi:10.1007/s00442-0112067-0.

Jones FA, Erickson DL, Bernal MA, Bermingham E, Kress WJ, Herre EA, MullerLandau HC, Turner BL (2011) The roots of diversity: below ground species richness and rooting distributions in a tropical forest revealed by DNA barcodes and inverse modeling. PLoS ONE 6:e24506. doi:10.1371/journal.pone.0024506.

Kiers ET, Lovelock CE, Krueger EL, Herre EA (2000) Differential effects of tropical arbuscular mycorrhizal fungal inocula on root colonization and tree seedling growth: implications for tropical forest diversity. Ecol Lett 3:106-113. doi: 10.1046/j.1461-0248.2000.00126.x.

Kimura M (1980) A simple method for estimating evolutionary rates of base substitutions through comparative studies of nucleotide sequences. J Mol Evol 16, 111-120.

Kivlin SN, Hawkes CV, Treseder KK (2011) Global diversity and distribution of arbuscular mycorrhizal fungi. Soil Biol Biochem 43: 2294-2303. doi:10.1016/j.soilbio.2011.07.012.

Koch AM, Croll D, Sanders IR. (2006) Genetic variability in a population of arbuscular mycorrhizal fungi causes variation in plant growth. Ecol Lett 9:103-110. doi: 10.1111/j.1461-0248.2005.00853.x.

Kohout $P$, Sudová R, Janoušková $M$, Čtvrtlíková $M$, Hejda $M$, Pánková $H$, Slavíková R, Štajerová K, Vosátka M, Sýkorová Z (2014) Comparison of commonly used primer sets for evaluation of arbuscular mycorrhizal fungal communities: Is there a universal solution? Soil Biol Biochem 68:482-493. doi:10.1016/j.soilbio.2013.08.027.

Lee J, Lee S, Young JPW (2008) Improved PCR primers for the detection and identification of arbuscular mycorrhizal fungi. FEMS Microbiol Ecol 65:33949. doi:10.1111/j.1574-6941.2008.00531.x.

Lovelock CE, Andersen K, Morton JB (2003) Arbuscular mycorrhizal communities in tropical forests are affected by host tree species and environment. Oecologia 135:268-279. doi:10.1007/s00442-002-1166-3.

Martin J, Béreau M, Louisanna E, Ocampo JA (2001) Arbuscular mycorrhizas in Dicorynia guianensis and Eperua falcata trees from primary tropical rain forest of French Guiana. Symbiosis 31:283-291. DOI

Michalet S, Rohr J, Warshan D, Bardon C, Roggy J-C, Domenach A-M, Czarnes S, Pommier T, Combourieu B, Guillaumand N, Bellvert F, Comte G, Poly F (2013) Phytochemical analysis or mature tree root exudates in situ and their role in shaping soil microbial communities in relation to tree $\mathrm{N}$-acquisition strategy. Plant Physiol Biochem doi:10.1016/j.plaphy.2013.05.003.

Mortimer PE, Pérez-Fernández MA, Valentine AJ (2008) The role of arbuscular mycorrhizal colonization in the carbon and nutrient economy of the tripartite symbiosis with nodulated Phaseolus vulgaris. Soil Biol Biochem 40:1019-1027. doi:10.1016/j.soilbio.2007.11.014. 
Munkvold L. Kjøller R, Vestberg M, Rosendahl S, Jakobsen I (2004) High functional diversity within species of arbuscular mycorrhizal fungi. New Phytol 164:357-364. doi:10.1111/j.1469-8137.2004.01169.x.

Oksanen J, Blanchet FG, Kindt R, Legendre P, Minchin PR, O'Hara RB, Simpson GL, Solymos P, Stevens MHH, Wagner H. (2015) vegan: Community Ecology Package. R package version 2.2-1. http://cran.r-project.org/package=vegan

Öpik M, Moora M, Liira J, Kõljalg U, Zobel M, Sen R. (2003) Divergent arbuscular mycorrhizal fungal communities colonize roots of Pulsatilla spp. in boreal Scots pine forest and grassland soils. New Phytol 160:581-593. doi:10.1046/j.1469-8137x.2003.00917.x.

Öpik M, Vanatoa A, Vanatoa E, Moora M, Davison J, Kalwij JM, Reier Ü, Zobel M (2010) The online database MaarjAM reveals global and ecosystemic distribution patterns in arbuscular mycorrhizal fungi (Glomeromycota). New Phytol 188:223-241. doi:10.1111/j.1469-8137.2010.03334.x.

Öpik M, Zobel M, Cantero JJ, Davison J, Facelli JM, Hiiesalu I, Jairus T, Kalwij JM, Koorem K, Leal ME, Liira J, Metsis M, Neshataeva V, Paal J, Phosri C, Põlme S, Reier Ü, Saks Ü, Schimann H, Thiéry O, Vasar M, Moora M (2013) Global sampling of plant roots expands the described molecular diversity of arbuscular mycorrhizal fungi. Mycorrhiza 23:411-430. doi:10.1007/s00572013-0482-2.

Paradis E, Claude G, Strimmer K (2004) APE: analyses of phylogenetics and evolution in $R$ language. Bioinformatics 20:289-290. doi: 10.1093/bioinformatics/btg412.

Pizano C, Mangan SA, Herre EA, Eom AH, Dalling JW (2011) Above- and belowground interactions drive habitat segregation between two cryptic species of tropical trees. Ecology 92:47-56. doi:10.1890/09-1715.1.

Plassard C.,Dell B. (2010) Phosphorus nutrition of mycorrhizal trees. Tree Physiol 30:1129-1139. doi: 10.1093/treephys/tpq063.

Poszwa A, Ferry B, Pollie B, Grimaldi C, Charles-Dominique P, Loubet M, Dambrine $\mathrm{E}$ (2009) Variations of plant and soil ${ }^{87} \mathrm{Sr} /{ }^{86} \mathrm{Sr}$ along the slope of a tropical inselberg. Ann For Sci 66:512. doi:10.1051/forest/2009036.

R Core Team (2015) R: a language and environment for statistical computing. R Foundation for Statistical Computing, Vienna, Austrai. http://www.Rproject.org/.

Ridgway KP, Duck JM, Young JPW (2003) Identification of roots from grass swards using PCR-RFLP and FFLP of the plastid trnL (UAA) intron. BMC Ecol 3:8. doi:10.1186/1472-6785-3-8.

Roger A, Colard A, Angelard C, Sanders IR (2013) Relatedness among arbuscular mycorrhizal fungi drives plant growth and intraspecific fungal coexistence. ISME J 7:2137-2146. doi:10.1038/ismej.2013.112.

Saitou N, Nei, M. (1987) The neighbor-joining method: a new method for reconstructing phylogenetic trees. Mol Biol Evol 4:406-425.

Sheublin TR, Ridgway KR, Young JPW, van der Heijden MGA et al. (2004) Nonlegumes, legumes, and root nodules harbor different arbuscular mycorrhizal fungal communities. Appl Environ Microbiol 70:6240-6246. doi: 10.1128/AEM.70.10.6240-6246.2004.

Schimann H, Ponton S, Hättenschwiler S, Ferry B, Lensi R, Domenach A-M, Roggy J-C (2008) Differing nitrogen use strategies of two tropical rainforest late successional tree species in French Guiana: evidence from ${ }^{15} \mathrm{~N}$ natural abundance and microbial activities. Soil Biol Biochem 40:487-494. doi:10.1016/j.soilbio.2007.09.011.

Schneider CA, Rasband WS, Eliceiri KW (2012) NIH Image to ImageJ: 25 years of image analysis. Nat Methods 9:671-675. doi:10.1038/nmeth.2089. 
Shendure J, Ji H (2008) Next-generation DNA sequencing. Nat Biotechnol 26:1135-1145. doi:10.1038/nbt1486.

Simon L, Lalonde M, Bruns TD (1992) Specific amplification of 18 S fungal ribosomal genes from vesicular-arbuscular endomycorrhizal fungi colonizing roots. Appl Environ Microbiol 58: 291-295. DOI

Slik JWF et al. (2015) An estimate of the number of tropical tree species. Proc Natl Acad Sci USA 112:7272:7477. doi:10.1073/pnas.1423147112.

Smith SE, Read DJ (2008) Mycorrhizal Symbiosis, 3rd edn. Academic Press, New York, USA.

Smith, SE, Smith FA (1997) New Phyt. 137: 373-388.

Sprent JI (2001) Nodulation in Legumes. Royal Botanic Gardens, Kew, UK.

Stürmer SL, Siqueira JO (2011) Species richness and spore abundance of arbuscular mycorrhizal fungi across distinct land uses in Western Brazilian Amazon. Mycorrhiza 21:255-267. doi: 10.1007/s00572-010-0330-6.

Sýkorová Z, Wiemken A, Redecker D. (2007) Cooccurring Gentiana verna and Gentiana acaulis and their neighboring plants in two Swiss upper montane meadows harbor distinct arbuscular mycorrhizal fungal communities. Appl Environ Microbiol 73: 5426-5434. doi: 10.1128/AEM.00987-07.

Taberlet P, Gielly L, Pautou G, Bouvet J (1991) Universal primers for amplification of three non-coding regions of chloroplast DNA. Plant Mol Biol. 17:11051109. doi:10.1007/BF00037152.

ter Steege H, Pitman NCA, Phillips OL, Chave J, Sabatier D, Duque A, Molino J-F, Prévost M-F, Spichiger R, Castellanos H, von Hildebrand P, Vásquez R (2006) Continental-scale patterns of canopy tree composition and function across Amazonia. Nature 443:444-447. doi:10.1038/nature05134.

Thompson JD, Higgins DG, Gibson TJ (1994) CLUSTAL W: improving the sensitivity of progressive multiple sequence alignment through sequence weighting, position-specific gap penalties and weight matrix choice. Nucl Acids Res 22:4673-4680. doi:10.1093/nar/22.22.4673.

van der Heijden MGA, Boller T, Wiemken A, Sanders IR (1998) Different arbuscular mycorrhizal fungal species are potential determinants of plant community structure. Ecology 79:2082-2091. doi:10.1890/00129658(1998)079[2082:DAMFSA]2.0.CO;2

van der Heijden MGA, Martin FM, Selosse M-A, Sanders IR (2015) Mycorrhizal ecology: the past, the present, and the future. New Phytol 205:1406-1423. doi:10.1111/nph.13288.

Vandenkoornhuyse P, Husband R, Daniell TJ, Watson IJ, Duck JM, Fitter AH, Young JPW (2002) Arbuscular mycorrhizal community composition associated with two plant species in a grassland ecosystem. Mol Ecol 11:1555-1564. doi:10.1046/j.1365-294X.2002.01538.x.

Werner GDA, Kiers ET (2015) Order of arrival structures arbuscular mycorrhizal colonization of plants. New Phytol 205: 1515-1524. doi: 10.1111/nph.13092.

Zeng W, Zou B, Lei P, Zeng Y, Liu Y, Liu C, Xiang W (2015) A molecular method to identify species of fine roots and to predict the proportion of a species in mixed samples in subtropical forests Front Plant Sci 6:313. doi: 10.3389/fpls.2015.00313. 
791 Table 1: trnL amplicon length predictions and measurements 792 for three co-occurring legume trees at Nouragues in French 793 Guiana. The sequence accession and identity used for 794 prediction is indicated in parentheses in the central column.

\begin{tabular}{|l|l|l|}
\hline Species & trnL length prediction & $\begin{array}{l}\text { Measurement } \\
\text { range }\end{array}$ \\
\hline $\begin{array}{l}\text { Dicorynia } \\
\text { guianensis }\end{array}$ & $\begin{array}{l}\text { 617 (FJ039291; Dicorynia } \\
\text { guianensis) }\end{array}$ & $616-618$ \\
\hline $\begin{array}{l}\text { Eperua } \\
\text { falcata }\end{array}$ & $\begin{array}{l}\text { 706 (FJ039126; Eperua } \\
\text { falcata) }\end{array}$ & $704-705$ \\
\hline $\begin{array}{l}\text { Tachigali } \\
\text { melinonii }\end{array}$ & $\begin{array}{l}\text { 578 (AF430790; Tachigali } \\
\text { paniculata) }\end{array}$ & $578-580$ \\
\hline
\end{tabular}


796 Table 2: Soil chemical characteristics (mean \pm standard 797 error) found around three co-occurring legume trees on two 798 soil types ('Grand Plateau' and 'Petit Plateau') at Nouragues 799 in French Guiana. Significant differences (t-test, $p<0.05$ ) 800 between plateaus are marked with an asterisk and 801 significant differences (Tukey's test, $\boldsymbol{p}<0.05$ ) between tree 802 species are noted with letters; absence of asterisk or stars 803 indicates no significant differences.

\begin{tabular}{|c|c|c|c|c|c|c|}
\hline & $\begin{array}{l}\text { Grand } \\
\text { Plateau }\end{array}$ & & $\begin{array}{l}\text { Petit } \\
\text { Plateau }\end{array}$ & $\begin{array}{l}\text { Dicorynia } \\
\text { guianensis }\end{array}$ & $\begin{array}{l}\text { Eperua } \\
\text { falcata }\end{array}$ & $\begin{array}{l}\text { Tachigali } \\
\text { melinonii }\end{array}$ \\
\hline $\mathrm{pH}$ & $\begin{array}{l}4.39 \pm \\
0.10\end{array}$ & & $\begin{array}{l}4.26 \pm \\
0.06\end{array}$ & $4.28 \pm 0.06$ & $4.38 \pm 0.26$ & $\begin{array}{l}4.36 \pm \\
0.10\end{array}$ \\
\hline C (\%) & $\begin{array}{l}7.74 \pm \\
0.73\end{array}$ & & $\begin{array}{l}6.05 \pm \\
0.62\end{array}$ & $\begin{array}{l}5.79 \pm 0.53 \\
a\end{array}$ & $\begin{array}{l}10.04 \pm \\
1.05 \mathrm{~b}\end{array}$ & $\begin{array}{l}6.78 \pm \\
0.71 \mathrm{a}\end{array}$ \\
\hline $\mathrm{N}(\%)$ & $\begin{array}{l}0.56 \pm \\
0.03\end{array}$ & * & $\begin{array}{l}0.39 \pm \\
0.03\end{array}$ & $\begin{array}{l}0.38 \pm 0.02 \\
a\end{array}$ & $\begin{array}{l}0.64 \pm 0.05 \\
b\end{array}$ & $\begin{array}{l}0.52 \pm \\
0.04 \mathrm{~b}\end{array}$ \\
\hline Tot. $\mathrm{P}\left(\mu \mathrm{g} \mathrm{g}^{-1}\right)$ & $430 \pm 33.5$ & $*$ & $\begin{array}{l}104 \pm \\
9.2\end{array}$ & $124 \pm 27 a$ & $325 \pm 55 a b$ & $419 \pm 58 b$ \\
\hline Extr. $P\left(\mu g^{-1}\right)$ & $16.1 \pm 2.6$ & & $\begin{array}{l}12.6 \pm \\
2.1 \\
\end{array}$ & $\begin{array}{l}10.3 \pm 0.9 \\
a\end{array}$ & $\begin{array}{l}25.4 \pm 4.6 \\
b\end{array}$ & $\begin{array}{l}13.9 \pm 2.4 \\
a\end{array}$ \\
\hline Extr. $\mathrm{K}\left(\mu \mathrm{g} \mathrm{g}^{-1}\right)$ & $167 \pm 15$ & * & $105 \pm 11$ & $100 \pm 8.0 \mathrm{a}$ & $\begin{array}{l}204 \pm 10.3 \\
b\end{array}$ & $\begin{array}{l}149 \pm \\
18.0 \mathrm{a}\end{array}$ \\
\hline Extr. Ca $\left(\mu \mathrm{g} \mathrm{g}^{-1}\right)$ & $965 \pm 322$ & * & $384 \pm 95$ & $401 \pm 105$ & $1607 \pm 896$ & $598 \pm 153$ \\
\hline $\begin{array}{l}\text { Extr. } \mathrm{Mg}(\mu \mathrm{g} \mathrm{g} \\
\left.{ }^{1}\right)\end{array}$ & $250 \pm 37$ & & $175 \pm 17$ & $175 \pm 19 a$ & $324 \pm 79 b$ & $\begin{array}{l}208 \pm 32 \\
a b\end{array}$ \\
\hline
\end{tabular}


805 Figure 1a: Rarefaction curves and 1b: frequency 806 distributions of the DGGE bands of arbuscular mycorrhizal 807 fungal taxa found on three co-occurring legume trees at 808 Nouragues in French Guiana.

809

810 
811 Figure 2: Venn diagram of the DGGE bands of arbuscular 812 mycorrhizal fungal taxa found on three co-occurring legume 813 trees at Nouragues in French Guiana.

814

815

816 
817 Figure 3: Redundancy analysis of DGGE bands of arbuscular 818 mycorrhizal fungal taxa on three co-occurring legume trees 819 at Nouragues in French Guiana constrained by soil nitrogen 820 concentration. Circles (green) = Dicorynia guianensis, 821 triangles $($ blue) $=$ Eperua falcata, Plus-signs $($ red $)=$ Tachigali 822 melinonii.

823

824 
825 Figure 4: Phylogenetic tree (neighbour-joining) of arbuscular 826 mycorrhizal fungi (Glomeromycota) on three co-occurring 827 legume trees at Nouragues in French Guiana. Filled dots

828 denote sequences derived from this study, open triangles 829 denote sequences from MaarjAM including Dicorynia 830 guianensis and Eperua falcata from Öpik et al. (2013) and 831 open squares denote sequences from Genbank. Numbers 832 indicate bootstrap values $(>\quad 50 \%$ shown; 100 833 randomisations). 
836 Supplementary Figure: a) Roots of Dicorynia guianensis in 837 situ b) Roots of Eperua falcata c) Roots of Tachigali melinonii 838 with spherical nodules.

839 